\title{
Acknowledgments
}

IN THE PROCESS of writing this book over the past several years, I have been fortunate enough to have had the constructive criticism and encouragement of the following friends and associates who have read parts or all of this book in manuscript form: the late Professor J. W. Davidson of the Institute of Advanced Studies, The Australian National University, who also had served over the years as senior consultant to the committees on political status of the Congress of Micronesia; Professor Emeritus Leonard Mason, formerly of the University of Hawaii; Robert Trumbull, chief of bureau, South Pacific, the New York Times; Dwight Heine, special consultant to the High Commissioner; and James Manke, chief of the division of public information, Trust Territory government.

I am also grateful to the editors of The Journal of Pacific History for giving me their permission to reproduce my article from volume four of that journal, 1969. This article is presented in slightly different form as chapter 8 of this book. Also I want to thank Dr. Marion W. Ward, editor of the Politics of Melanesia, for allowing me to reprint my article, which was published in that book by the University of Papua and New Guinea, and the Research School of Pacific Studies, The Australian National University, 1971. This article formed the basis of chapter 16 of this book.

I particularly want to offer my appreciation to two former Peace Corps attorneys, W. Stephen Miller and Michael A. White, both of whom are now working for the Congress of Micronesia. 


\section{xiv Acknowledgments}

They each have read portions of the manuscript and have extended aid and advice during the writing of this book.

I also want to record my gratitude to Margaret Kanost for her aid in the compilation of the index for this book, and to Iris Falcam, former librarian of the Congress of Micronesia who was always cheerful and ready to offer assistance in locating needed research materials.

I wish to acknowledge my debt to Evelyna Akimoto who not only typed and retyped the manuscript in its entirety, but helped as research assistant. To her I extend my sincere appreciation.

Finally, I want to express my appreciation to the Joint Committee on Future Status of the Congress of Micronesia and especially to its chairman, Senator Lazarus E. Salii, for giving me the rare opportunity to work closely with the Joint Committee in its negotiations. I thus was able to observe some of the problems affecting Micronesia's future status at close range. I am equally grateful to High Commissioner Edward E. Johnston for granting me leave of absence from my job in the Executive Branch so that I could work with the Joint Committee on Future Status.

I owe special gratitude to Janyce $\mathrm{K}$. Blair whose suggestions and editing of the manuscript were most welcome.

I cannot close without thanking my wife, Susan, who provided a perfect home environment in which I was able to complete this study.

Needless to say, I, alone, am responsible for the contents, opinions, and conclusions of this book. 